\title{
Studies on various Nitrogen Level and Plant Growth Regulators on Plant Dry Weight, CGR and Yield Attribute of Maize (Zea mays L.)
}

\author{
Prakhar Maurya*, Joy Dawson, Ravi Ranjan Kumar and Alok Kumar Verma \\ Department of Agronomy, Naini Agriculture institute, SHUATS, Prayagraj-211007, \\ Uttar Pradesh, India \\ *Corresponding author
}

Keywords

staple food, corn oil, corn flakes and corn sugar

Article Info

Accepted:

12 March 2021

Available Online:

10 April 2021
Maize is one of the most important cereal crops in India contributing significantly towards food and nutritional security. The experiment was carried out to study the effect of nitrogen levels and plant growth regulator (PGR) on plant dry weight, crop growth rate (CGR) and yield attributes in maize crop. The experiment was conducted during Rabi season of 2019-20 at Crop Research Farm, Department of Agronomy, Naini Agricultural Institute, SHUATS, Prayagraj (U.P.). The experiment was laid down in RBD having 12 treatments with three replicates. Experimental results found that the treatment $10(120 \mathrm{~kg}$ Nitrogen + NAA $40 \mathrm{ppm})$ had higher plant height $(181.66 \mathrm{~cm})$, higher plant dry weight at 60 DAS $(5.08 \mathrm{~g}), 100$ DAS $(19.60 \mathrm{~g})$ and at harvest $(95.83 \mathrm{~g})$, Higher Crop Growth Rate at $60-80$ DAS $\left(0.12 \mathrm{~g} / \mathrm{m}^{2} /\right.$ day $), 80-100$ DAS $\left(0.61 \mathrm{~g} / \mathrm{m}^{2} /\right.$ day $)$ and At Harvest $\left(1.08 \mathrm{~g} / \mathrm{m}^{2} /\right.$ day $)$ and in yield attributes i.e. maximum Number of cob/plant $(2.30 \mathrm{cob} /$ plant $)$ Cob length $(13.86 \mathrm{~cm})$, Maximum 100 seed weight $(31.50 \mathrm{~g})$, Maximum Grain yield $(5015.33 \mathrm{~kg} / \mathrm{ha})$ also in treatment 10 (120 kg Nitrogen + NAA $40 \mathrm{ppm}$ ) with maximum B:C ratio of 2.17 followed by treatment $12(120 \mathrm{~kg}$ Nitrogen + Putrescine $50 \mathrm{ppm})$. Thus, it may be concluded that use of nitrogen @120 kg/ha with Naphthalene Acetic Acid (NAA@40ppm is beneficial during Rabi season in maize crop leading to better yield attributes and return from the crop.

\section{Introduction}

Maize is the most important cereal crop of the world after wheat and rice, growing everywhere in the irrigated as well as in rainfed areas. It is staple food of rural population in India. As a grain crop, maize is a rich source of food and it is also used on large scale in industries for manufacturing of corn oil, corn flakes and corn sugar. This crop is gaining momentum in earning foreign exchange besides higher economic returns to the farmers. Thus, it is essential to enhance agronomic practices for maize growing and improving productivity per hectare through inclusion of growth promoters and increased nitrogen levels in the crop agronomic practices. 
Levels of nitrogen application based on the requirements is important to increase the total biological yield leading to higher productivity. Growth regulators can improve the effective partitioning and translocation of assimilates from source to sink in the field crops. Being a new plant type, the response on different plant growth regulators and split application of nitrogen under irrigated conditions was thought to be experimented.

Nitrogen plays significant role in improving soil fertility and increasing crop productivity. Nitrogen fertilizer results in an increased grain yield (43-68\%) and biomass (25- 42\%) in maize. Chemical fertilizer application could not be avoided completely since they are the potential sources of high amount of nutrients in easily available forms and maize is more responsive to it.

An increase in yield of maize with increasing rate of nitrogen has been reported by many researchers primarily due to its favourable effect on yield components of maize (Shivay and Singh, 2000;Raja, 2001; Ayub et al., 2003; Namakka et al., 2008).

PGRs are chemical substances, when applied in small quantities, can rapidly change the physiology and phenotype of the plant. They enhance or stimulate the natural growth regulatory system prompting growth of the plant from germination of seed till the senescence. PGRs improve the source to sink relationship and help in stimulating the translocation of photosynthates there by aid in formation of flowers and development of fruit seed resulting in enhanced crop productivity. Among various PGRs, Mepiquat Chloride (MC) is a water soluble plant growth regulator when sprayed on the plant, acts systematically after its absorption by plant leaves. It acts as a gibberellic acid inhibitor and inhibits cell elongation there by reducing the longitudinal growth of the plant. It has also shown to be useful in determinate crops. The chemical namely diamine putrescine occurs extensively in higher plants and is believed to have involvement in various growth and developmental processes such as cell division fruit set growth and senescence. The interaction between polyamines and macromolecules is believed to be reason for physiologically affecting the growth and development of the plant. NAA (auxin) promotes vegetative growth by enhancing cell division, enlargement and elongation, thus helping in improvement of growth characteristics and reproductive growth stimulation.

PGRs, either promoters or retardants can be used to change the morphology of plant by affecting the stem length and leaf size. Growth retardants on one side can reduce the canopy of the plant there by allowing higher and rapid translocation of photosynthates towards sink i.e. green young cob and on other side, growth promoters can enhance the overall growth of plant resulting in more leaf area and thus more photosynthesis. PGRs can also lead to better physiological efficiency of plant such as photosynthetic ability which can improve effective partitioning of the photosynthetic assimilates from source to sink. Application of PGRs in the form of foliar spray at pre flowering stage helps in improving physiological efficiency along with crop productivity.

\section{Materials and Methods}

The experiment was carried out during Rabi season of 2019-2020 at Crop Research Farm, Department of Agronomy, Naini Agricultural Institute, SHUATS, Prayagraj (U.P.) which is located at $25024^{\prime} 42^{\prime \prime} \mathrm{N}$ latitude, 810 50' 56" E longitude and $98 \mathrm{~m}$ altitude above the mean sea level. The soil of the experimental field was sandy loam in texture having $\mathrm{pH}$ 7.4, medium in available NPK but low in organic 
carbon i.e. $0.03 \%$. The experiment was conducted in Randomized Block Design consisting of 12 treatments combinations with 3 replications and was allocated randomly in each replication The experimental crop were raised by using K-27 variety of maize which is High yielding variety and recommended for U. P. The crop was sown on 16 November 2019.

\section{Statistical Analysis}

The experimental data was collected to analyse statistically by Fishers method of Analysis (ANOVA) as outline by Gomen and Gomez (2010). Critical Difference (CD) value were calculated whenever the $\mathrm{F}$ test value was found significant at 5\% level.

\section{Results and Discussion}

At the time of harvesting of maize the significant and maximum plant height (181.66 $\mathrm{cm})$ was recorded in treatment $10(120 \mathrm{~kg}$ Nitrogen + NAA 40 ppm), however treatment $6[100 \mathrm{~kg} / \mathrm{ha}$ Nitrogen + NAA $40 \mathrm{ppm}]$ and 12 (120 kg Nitrogen + Putrescine $50 \mathrm{ppm}]$ was found to be at par with treatment $10(120 \mathrm{~kg}$ Nitrogen + NAA 40 ppm)

The increase in plant height might be due to the plant growth regulator which had significant impact on the growth regulation of the various crops especially maize Plant growth was maximum in NAA treated group, the pattern of growth rate remained same at harvest stage of the crop when it reached to $181.66 \mathrm{~cm}$ in NAA followed by putrescine group i.e. $177.66 \mathrm{~cm}$. Plant growth observation confirmed their consistent effect on the crop till harvest. Nargis and Nilufar, (2017) have also reported increased plant height while using NAA in maize crop.

The plant dry weight (g) was analyzed and presented in the table-1, Fig.1. The data was significant at 80 DAS and at harvesting, while at 80 DAS. The plant dry weight was found to non- significant. Maximum plant dry weight $(19.6 \mathrm{~g})$ was found at 100DAS in treatment 9 (120 kg/ha Nitrogen) however, treatment 12 was found at par with treatment 9 and at the time of harvesting. Maximum plant dry weight $(95.83 \mathrm{~g})$ was found in treatment $9(120 \mathrm{~kg} / \mathrm{ha}$ Nitrogen) however, treatment 6 and12 were found at par with treatment 9, while at 80 DAS the maximum plant dry weight $(7.42 \mathrm{~g})$ was found in treatment $9(120 \mathrm{~kg} / \mathrm{ha}$ Nitrogen $)$ though non-significant.

It revealed that higher level of nitrogen application results in better plant and foliage growth in turn also resulting into higher yield of plant dry weight. Plant dry weight is a physiological process governed by photosynthetic rate and photosynthesizing area. Photosynthetic rate is influenced by temperature. Differences in temperature and in leaf area per plant i.e. photosynthesizing area lead to differences in dry matter accumulation (Hai-dong et al., 2017). In the present study, higher level of nitrogen must have contributed towards increase foliage and plant growth leading to more dry weight of the plant in this group.

The Crop growth rate of maize $\left(\mathrm{g} / \mathrm{m}^{2} /\right.$ day) was analyzed and presented in table-1, Fig. 2, the data was significant at 80-100 DAS and 100 to at harvesting, while at 20-40 DAS, 40-60 DAS and 60-80 DAS it was found to be nonsignificant. At 80-100 DAS the significant and maximum Crop growth rate $\left(0.61 \mathrm{~g} / \mathrm{m}^{2} /\right.$ day $)$ was observed in treatment $10(120 \mathrm{~kg}$ Nitrogen + NAA 40 ppm) however, treatment 12 was found at par with treatment 10 and at 100 DAS to harvest. Maximum Crop growth rate $(1.08 \mathrm{~g} / \mathrm{m} 2 /$ day $)$ was observed in treatment $10(120 \mathrm{~kg}$ Nitrogen + NAA 40 ppm) however, treatment 2, 4, 6, 8, 9 and 12 were found at par with treatment 10 . At $60-80$ DAS the maximum Crop growth rate $(0.12$ 
$\mathrm{g} / \mathrm{m}^{2} /$ day) was observed in treatment $10(120$ $\mathrm{kg}$ Nitrogen + NAA $40 \mathrm{ppm}$ ) though nonsignificant

Tajul et al., (2013) stated that regardless of treatments, CGR increases progressively and time reaching peak during 50-60 DAS and thereafter declined till maturity. Reduction in growth rate with plant age was probably due to cessation of vegetative growth, loss of leaves and senescence. Similar reduction in the maize and in the late season of forage maize was also reported by Padmja (1999) and Okpara, Omaliko (1999).Treatment variations during the later growth period was not significant though the differences were apparent in initial stages.

Among the nitrogen levels, $120 \mathrm{~kg} / \mathrm{ha}$. showed maximum CGR throughout growth period followed by $100 \mathrm{~kg} \mathrm{~N} / \mathrm{ha}$. In general, increase in planting density increased CGR in all the nitrogen levels; CGR response to population density and nitrogen rates followed a linear relationship suggesting that 97 and $99 \%$ of total variation in CGR could be accounted for by the linear function of nitrogen and PGR, respectively. Therefore, the functional relationship suggests that higher the nitrogen levels and population density, the greater would be the CGR of maize plant.

The maximum Number of cob/plant (2.3 cob/plant) was found in treatment $10(120 \mathrm{~kg}$ Nitrogen + NAA $40 \mathrm{ppm})$ and followed by $2.20 \mathrm{cob} /$ plant in treatment $6(100 \mathrm{~kg} / \mathrm{ha}$ Nitrogen + NAA $40 \mathrm{ppm}), 9(120 \mathrm{~kg} / \mathrm{ha}$ Nitrogen) and $12 \quad(120 \quad \mathrm{~kg}$ Nitrogen + Putrescine 50 ppm) (table-2).

Application of nitrogen in three split doses must have helped in continuous supply of nitrogen to plants to maintain greenness of leaves for longer period which in turn helped in higher grain yield which might have contributed much to the developing sink and thereby increased the seed weight of maize. (Misra et al., 1994). Application of nitrogen in three split doses is conductive for regulating the supply of fertilizer nitrogen over the whole of the active growth phase of plant. Increase in yield under nitrogen may also be due to the fact that when a considerable amount of nitrogen is applied at or near to anthesis, there is a greater possibility of its accumulation in sink rather than in other vegetative parts, in PGR group, the weight of the grains varied from 26.7-30.2 $\mathrm{g}$ with significant increase in NAA and Putrescine group whereas it was similar in Mepiquat Chloride and control.

Present findings are in agreement with Rahman et al., (2016), they have also reported 100 grains weight at $25.27 \mathrm{~g}$, similar findings have also been reported by Gul et al., (2015).

The significant and maximum cob weight without husk $(72.8 \mathrm{~g})$ was found in treatment $10(120 \mathrm{~kg}$ Nitrogen + NAA $40 \mathrm{ppm})$ however, treatment 12 was also found to be at par with treatment 10 . The reasons for variation in dehusked cob yield under different treatment would also be same as those explained for differences in husked cob yield. These results are in agreement with Rajablarijani et al., (2014) and Shrestha et al., (2016).

The significant variation in 100 seed weight was observed maximum in 100 seed weight $(31.5 \mathrm{~g})$ was found in treatment $10(120 \mathrm{~kg}$ Nitrogen + NAA $40 \mathrm{ppm}$ ) however treatment 12 (120 kg Nitrogen + Putrescine 50 ppm) was found to be at par with treatment 10 .

The significant and maximum grain yield $(5015.33 \mathrm{Kg} / \mathrm{ha})$ was recorded in treatment 10 (120 kg Nitrogen + NAA 40 ppm) However treatment $6(100 \mathrm{~kg} / \mathrm{ha}$ Nitrogen + NAA 40 $\mathrm{ppm})$ and 12 (120 kg Nitrogen + Putrescine 50 ppm) was found at par with treatment $10(120$ kg Nitrogen + NAA 40 ppm). 
Table.1 Effect of Nitrogen Level and Plant Growth Regulators on Growth attribute of maize

\begin{tabular}{|c|c|c|c|c|c|c|c|}
\hline \multirow[t]{2}{*}{ TREATMENT DETAILS } & \multirow{2}{*}{$\begin{array}{c}\text { Plant } \\
\text { height } \\
\text { At } \\
\text { Harvesting }\end{array}$} & \multicolumn{3}{|c|}{ PLANT DRY WEIGHT (g) } & \multicolumn{3}{|c|}{ CGR $\left(g / \mathrm{m}^{2} /\right.$ day $)$} \\
\hline & & 60DAS & 100DAS & $\begin{array}{c}\text { At } \\
\text { Harvesting }\end{array}$ & 60-80 DAS & $\begin{array}{l}80-100 \\
\text { DAS }\end{array}$ & $\begin{array}{l}\text { 100DAS - } \\
\text { at Harvest }\end{array}$ \\
\hline $1.80 \mathrm{~kg} / \mathrm{ha}$ Nitrogen & 139.00 & 4.42 & 11.55 & 80.200 & 0.09 & 0.25 & 0.98 \\
\hline $2.80 \mathrm{~kg} / \mathrm{ha}$ Nitrogen + NAA 40 ppm & 166.00 & 4.53 & 14.23 & 87.733 & 0.10 & 0.38 & 1.05 \\
\hline $\begin{array}{l}3.80 \mathrm{~kg} / \mathrm{ha} \text { Nitrogen + Mepiquat Chloride } \\
200 \mathrm{ppm}\end{array}$ & 132.00 & 4.26 & 9.85 & 75.800 & 0.10 & 0.17 & 0.94 \\
\hline 4. $80 \mathrm{~kg} / \mathrm{ha}$ Nitrogen + Putrescine 50 ppm & 162.33 & 4.55 & 13.55 & 86.533 & 0.08 & 0.36 & 1.04 \\
\hline $5.100 \mathrm{~kg} / \mathrm{ha}$ Nitrogen & 155.00 & 4.94 & 14.29 & 84.100 & 0.11 & 0.35 & 0.99 \\
\hline $6.100 \mathrm{~kg} / \mathrm{ha}$ Nitrogen + NAA 40 ppm & 175.00 & 4.87 & 17.32 & 91.400 & 0.10 & 0.51 & 1.05 \\
\hline $\begin{array}{l}\text { 7. } 100 \mathrm{~kg} / \mathrm{ha} \text { Nitrogen + Mepiquat Chloride } \\
200 \mathrm{ppm}\end{array}$ & 142.33 & 4.84 & 12.26 & 79.500 & 0.10 & 0.26 & 0.96 \\
\hline 8. $100 \mathrm{~kg} / \mathrm{ha}$ Nitrogen + Putrescine 50 ppm & 171.66 & 4.83 & 16.75 & 89.367 & 0.11 & 0.48 & 1.03 \\
\hline $9.120 \mathrm{~kg} / \mathrm{ha}$ Nitrogen & 162.00 & 5.05 & 16.45 & 88.167 & 0.11 & 0.45 & 1.02 \\
\hline 10. 120 kg Nitrogen + NAA 40 ppm & 181.66 & 5.08 & 19.60 & 95.833 & 0.12 & 0.61 & 1.08 \\
\hline $\begin{array}{l}11.120 \mathrm{~kg} \text { Nitrogen + Mepiquat Chloride } \\
200 \mathrm{ppm}\end{array}$ & 147.33 & 5.06 & 14.17 & 81.867 & 0.11 & 0.34 & 0.96 \\
\hline 12. $120 \mathrm{~kg}$ Nitrogen + Putrescine $50 \mathrm{ppm}$ & 177.66 & 5.00 & 18.92 & 93.767 & 0.11 & 0.58 & 1.06 \\
\hline F-test & $\mathrm{S}$ & NS & $\mathrm{S}$ & $\mathrm{S}$ & NS & $\mathrm{S}$ & $\mathrm{S}$ \\
\hline $\mathrm{Se}(\mathrm{m}) \pm$ & 3.30 & 0.261 & 0.39 & 1.889 & 0.027 & 0.02 & 0.02 \\
\hline $\mathrm{CD}(\mathrm{p}=0.05)$ & 9.74 & - & 1.16 & 5.575 & - & 0.08 & 0.07 \\
\hline
\end{tabular}


Table.2 Effect of Nitrogen Level and Plant Growth Regulators on yield attribute of maize

\begin{tabular}{|c|c|c|c|c|c|}
\hline TREATMENT DETAILS & $\begin{array}{l}\text { Number of } \\
\text { cobs/plant }\end{array}$ & $\begin{array}{c}\text { Cob length } \\
(\mathrm{cm})\end{array}$ & $\begin{array}{l}100 \text { grain } \\
\text { weight }(g)\end{array}$ & $\begin{array}{c}\text { Grain yield } \\
\text { (kg/ha) }\end{array}$ & B:C \\
\hline $1.80 \mathrm{~kg} / \mathrm{ha}$ Nitrogen & 2.13 & 9.567 & & & \\
\hline $2.80 \mathrm{~kg} / \mathrm{ha}$ Nitrogen + NAA 40 ppm & 1.93 & 11.367 & 26.36 & $3,563.33$ & 1.58 \\
\hline $3.80 \mathrm{~kg} / \mathrm{ha}$ Nitrogen + Mepiquat Chloride 200 ppm & 2.13 & 9.533 & 28.86 & $4,226.66$ & 1.85 \\
\hline 4. 80 kg/ha Nitrogen + Putrescine 50 ppm & 2.00 & 11.200 & 26.16 & $3,138.66$ & 1.35 \\
\hline $5.100 \mathrm{~kg} / \mathrm{ha}$ Nitrogen & 2.13 & 11.467 & 28.86 & $4,173.33$ & 1.79 \\
\hline 6. $100 \mathrm{~kg} / \mathrm{ha}$ Nitrogen + NAA 40 ppm & 2.20 & 13.333 & 27.30 & $3,933.66$ & 1.73 \\
\hline 7. $100 \mathrm{~kg} / \mathrm{ha}$ Nitrogen + Mepiquat Chloride 200 ppm & 1.93 & 11.133 & 30.43 & $4,778.00$ & 2.08 \\
\hline $8.100 \mathrm{~kg} / \mathrm{ha}$ Nitrogen + Putrescine $50 \mathrm{ppm}$ & 2.06 & 13.067 & 26.83 & $3,699.66$ & 1.58 \\
\hline $9.120 \mathrm{~kg} / \mathrm{ha}$ Nitrogen & 2.20 & 12.167 & 30.10 & $4,712.33$ & 2.01 \\
\hline 10. 120 kg Nitrogen + NAA 40 ppm & 2.30 & 13.867 & 27.73 & $4,122.00$ & 1.80 \\
\hline 11. 120 kg Nitrogen + Mepiquat Chloride 200 ppm & 2.06 & 11.900 & 31.50 & $5,015.33$ & 2.17 \\
\hline 12. 120 kg Nitrogen + Putrescine 50 ppm & 2.20 & 13.733 & 27.23 & $3,921.00$ & 1.67 \\
\hline F-test & NS & $\mathrm{S}$ & 30.80 & $4,962.00$ & 2.10 \\
\hline $\mathrm{Se}(\mathrm{m})$ & 0.083 & 0.284 & $\mathrm{~S}$ & S & - \\
\hline \multirow[t]{2}{*}{$\mathrm{CD}(\mathrm{p}=0.05)$} & - & 0.839 & 0.25 & 94.53 & - \\
\hline & & & 0.74 & 279.03 & - \\
\hline
\end{tabular}


Fig.1 Effect of Nitrogen Levels and Plant Growth Regulators on Plant dry weight

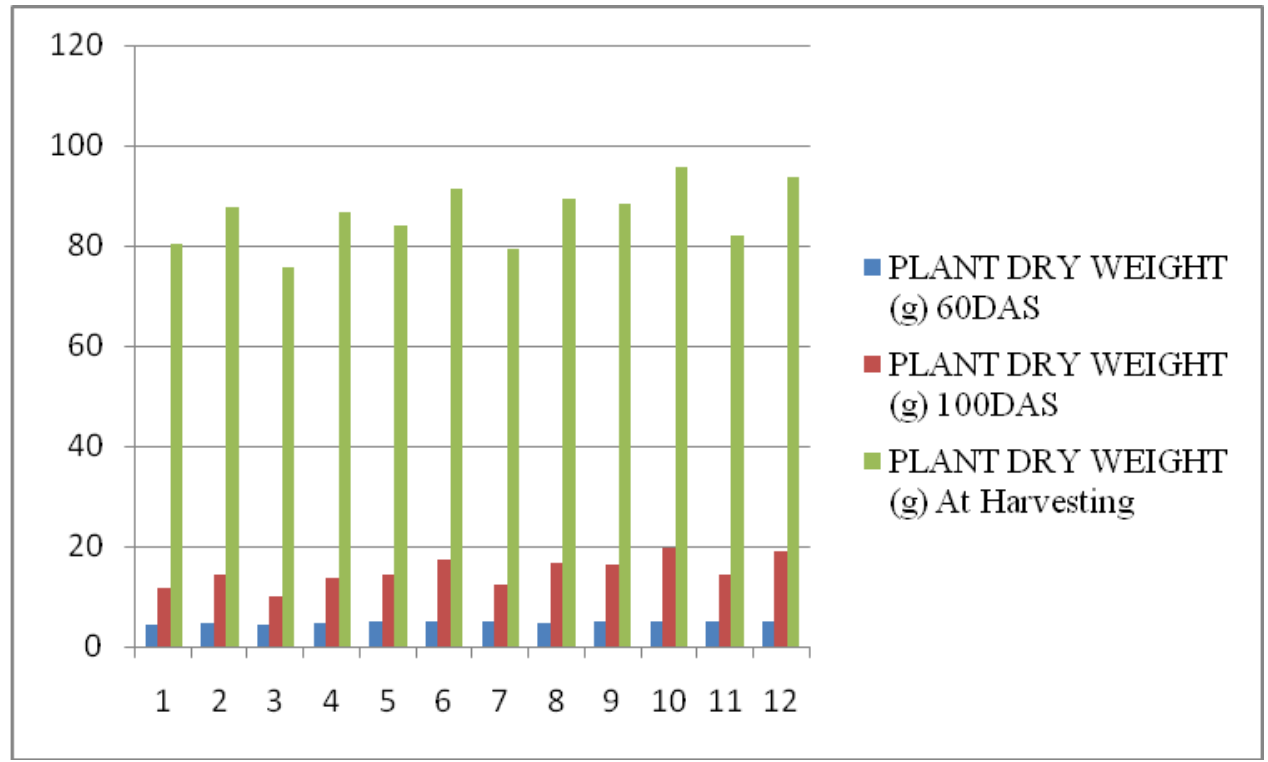

Fig.2 Effect of Nitrogen Levels and Plant Growth Regulators on Crop Growth Rate.

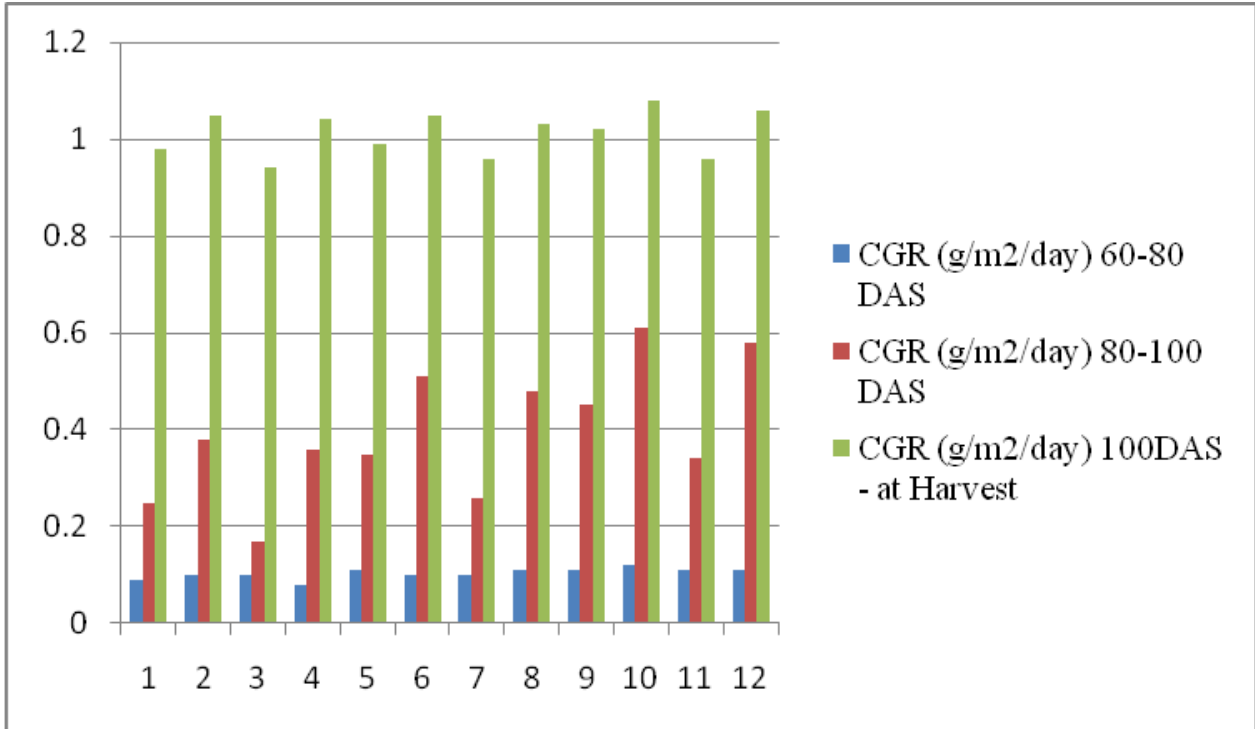

This improvement in grain yield might be due to an early and plentiful availability of nitrogen leading to better nutritional environment in the root zone for growth and development. As nitrogen is one of the major essential plant nutrients required for growth, increased availability of nitrogen might have increased cell number and cell size leading to better plant growth. Nitrogen is an element of chlorophyll; it harnesses solar energy and fixes atmospheric $\mathrm{CO}_{2}$ as carbohydrates and amino acids. Thus, nitrogen application increased dry matter production. The increase supply of nitrogen and their higher uptake by plants might have stimulated the rate of various physiological processes in plant and lead to increased growth parameters and yield attributes. The enhanced growth with nitrogen 
has also been reported by Bindhani et al., (2007), Sahoo and Mahapatra (2007), Gul et al., (2015) and Rahman et al., (2016). Foliar application of PGRs directly influences the plant vegetative growth that in turn results into higher yield in maize crop. The maximum B:C ratio (2.17) was recorded in treatment 10 and followed by treatment 12 (2.10)

From the above experiment it is concluded that treatment 10 (120 kg Nitrogen + NAA 40 ppm) have higher plant height, Plant dry weight, CGR, Maximum No. of cob/plant, Cob length $(\mathrm{cm})$, Maximum 100 seed weight, Maximum Grain yield (kg/ha), and Maximum B:C ratio. Thus, use of nitrogen @ $120 \mathrm{~kg} / \mathrm{ha}$ with Naphthalene Acetic Acid (NAA) @ 40 ppm in K-27 variety of maize during Rabi season in sandy soil having low carbon contents is beneficial to the farmer as recorded in planned experiment.

\section{References}

Ayub, M., Ahmad, R., Nadeem, M. A. and Khan, R. M. A. (2003) Effect of different levels of nitrogen and seed rates on growth, yield and quality of maize fodder. Pak J Agri Sci 40: 14043.

Bindhani M V., Velayudham $\mathrm{K}$ and Thavaprakaash N. (2007) PGRs and split application of nitrogen improves the quality parameters and green cob yield of baby corn (Zea mays L.). $J$ Agron6(1):208-11.

Dixit, P. Mahapatra. and Elamathi, Sahoo. (2007) Effect of foliar application of DAP, micronutrients and NAA on growth and yield of green gram (Vigna radiata L.). Leg. Res., 30(4): 305-307. Chandrasekhar, C. N. and Bangarusamy, U., 2003, Maximizing the yield of mung bean by foliar application of growth regulating chemicals and nutrients. Madras Agric.
J., 90(1-3): 142-145.

Dixit, P. Mahapatra and Elamathi, Sahoo. 2007. Effect of foliar application of DAP, micronutrient and NAA on growth and yield of green gram (Vigna radiata L.). Legume Research30(4):305-307.

Gomez, K. A., Gomez, A. A. 2010. Statistical procedures for agricultural research. $2^{\text {nd }}$ edn. Wiley India Pvt Ltd, India

Gul S. Khan M. H. Khanday B. A. and Nabi S. 2015. Effect of sowing method and NPK levels on growth and yield of rainfed maize. Hindawi publishing corporation scientific Volume 2015, Article ID 198575, 6 page

Jahan Nargis and Yasmin Nilufar 2017 Growth responses, pigment and stomatal behaviour of maize to foliar application of NAA. J. Bangladesh Acad. sci. 41(1):1-9.

Misra, B. N., Yadav, R. S., Rajput, A. L. and Pandey, S.M. 1994. Effect of plant geometry and nitrogen application on yield and quality of winter maize (Zea mays L.). Indian Journal of Agronomy 39(3):468-469.

Namakka, A., Abubakar, I. U., Sadik, I. A., Sharifai, A. I. and Hassas, A. H. (2008) Effect of sowing date and nitrogen levels on yield and yield components of two extra early maize varieties (Zea mays L.) in Sudan Savanna of Nigeria. APRN J Agric Biol Sci 3: 2.

Rahman, M. M., S. K. Paul and Rahman M. M. 2016. Effects of spacing and nitrogen levels on yield and yield contributing characters of maize $J$. Bangladesh Agril. Univ. 14(1): 43-48.

Raja, V. (2001) Effect of nitrogen and plant population on yield and quality of super sweet corn (Zea mays L.). Indian J Agron 46: 246-49.

Shivay, Y. S. and Singh, R. P. (2000) Growth, yield attributes, yield and nitrogen 
uptake of maize (Zea mays L.) as influenced by cropping systems and nitrogen levels. Ann Agric Res 21: 494-98.

Shrestha B. N., R. S., Singh, T. and Yadav, S.K. 2016. Effect of irrigation and fertility levels on nitrogen and phosphorus uptake in winter maize under shallow water table conditions in Haryana. Indian Journal of Soil Conservation 29(2) :135-136.

\section{How to cite this article:}

Prakhar Maurya, Joy Dawson, Ravi Ranjan Kumar and Alok Kumar Verma. 2021. Studies on various Nitrogen Level and Plant Growth Regulators on Plant Dry Weight, CGR and Yield Attribute of Maize (Zea mays L.). Int.J.Curr.Microbiol.App.Sci. 10(04): 351-359. doi: https://doi.org/10.20546/ijcmas.2021.1004.038 